\title{
ANALISIS KEMAMPUAN PEMECAHAN MASALAH SISWA SMP DALAM MENYELESAIKAN SOAL PADA MATERI ARITMATIKA SOSIAL
}

\author{
Fitrie Andayani ${ }^{1}$, Adiska Nadiyah Lathifah ${ }^{2}$ \\ 1,2 IKIP SILIWANGI, Jl. Jendral Sudirman, Cimahi 40526 \\ Fandayani1997@gmail.com
}

\begin{abstract}
The purposes of this research is to analyze the problem solving ability of student junior high school in solving social arithmetic test, the ability that hoped might by students is solving math test ability with good and true. Budiman states that fourt steps for solving the test, that are: identify sufficiency of data to solving the problem, make the model of math from any problem, pick and apply strategy for solving the problem, and then check the true of the result or the answer. The subjeck of this research is eighth grade of SMPN 3 CIMAHI that there are 36 students. The instrument that used by this study are test and interview. This study used qualitative descriptive method. Based on the analyze the data can concluded that the mistake that made by a lot of students is on the indicator understanding the problem. Student can not understand the question on social arithmetic material. On the made the math model indicator, pick the strategy of solving, problem solving, and check the result of the answer back just as student who can do on this step.
\end{abstract}

Keywords: Problem Solving Ability, Social Arithmetic

\begin{abstract}
Abstrak
Penelitian ini bertujuan untuk menganalisis kemampuan pemecahan masalah siswa SMP dalam menyelesaikan soal aritmatika sosial, kemampuan yang diharapkan dkuasai oleh siswa yakni kemampuan menyelesaikan soal matematika dengan baik dan benar. Budiman mengungkapkan 4 langkah penyelesaian soal, yakni: mengidentifikasi kecukupan data untuk memecahkan masalah, membuat model matematika dari suatu masalah, memilih dan menerapkan strategi untuk menyelesaikan masalah, serta memeriksa kebenaran hasil atau jawaban. Subjek penelitian ini adalah SMPN 3 CIMAHI kelas VIII-F terdiri dari 36 siswa. Instrumen yang digunakan adalah tes dan wawancara. Penelitian ini menggunakan pendekatan kualitatif dengan metode analisis deskriftif. Berdasarkan analisis data dapat disimpulkan bahwa kesalahan yang dilakukan siswa terbanyak pada indikator memahami masalah. Siswa tidak bisa memahami soal pada materi aritmatika sosial. Pada indikator membuat model matematika, memilih strategi penyelesaiaan, menyelesaikan masalah, dan memeriksa kembali hasil jawaban hanya sebagian siswa yang dapat mengerjakan pada tahap ini.
\end{abstract}

Kata Kunci : Kemampuan Pemecahan Masalah, Aritmatika Sosial

Matematika merupakan mata pelajaran yang harus bisa dikuasai dengan baik, namun secara umum mata pelajaran matematika dianggap sulit oleh sebagian siswa, maka tak heran tidak sedikit dari siswa yang tidak menyukai pelajaran ini, hal ini sejalan dengan pendapat Hendra (2018) bahwa matematika salah satu ilmu dasar yang mempunyai peranan penting dalam dunia pendidikan, karena pelajaran matemaika merupakan sarana yang dapat digunakan untuk membentuk siswa untuk berpikir secara ilmiah. Aburrahman (2010:252) mengatakan bahwa dari berbagai bidang studi yang dianggap sulit yang diajarkan di sekolah, matematika merupakan bidang studi yang dianggap paling sulit oleh siswa, baik yang tidak berkesulitan belajar dan bagi siswa yang berkesulitan belajar. Setiap individu mengalami kesulitan yang berbeda-beda, dari individu satu ke individu lainnya mempunyai konsep yang berbeda dalam menyelesaikan persoalan matematika. Siswa yang mengalami kesulitan belajar matematika sering melakukan kesalahan atau kekeliruan dalam belajar berhitung, maupun 
menyelesaikan soal cerita (Runtukahu dan Kandou, 2014:252). Kesulitan yang dialami siswa, memungkinkan siswa melakukan kekeliruan dalam menyelesaikan persoalan matematika (Untari, 2014:1). Hubungan antara kesulitan dan kesalahan bisa diperhatikan pada kalimat "Jika seorang siswa mengalami kesulitan maka ia akan membuat kesalahan" (Limardani, Trapsilasiwi, dan Fatahillah, 2015:2).

Kurangnya kemampuan pemecahan masalah siswa yang menyebabkan siswa hanya bisa mengerjakan soal rutin atau soal yang sama persis dengan yang diberikan oleh guru, sehingga siswa tidak dibiasakan mengerjakan soal yang tidak rutin yang mengakibatkan siswa mengalami kesalahankesalahan dalam menyelesaikan soal matematika. Kemampuan pemecahan masalah merupakan potensi yang dimiliki seseorang atau siswa dalam menyelesaikan soal cerita, menyelesaikan soal yang tidak rutin (berbeda-beda), mengaplikasikan matematika dalam kehidupan sehari-hari untuk menemukan solusi atau memecahkan persoalan yang terdapat pada matematika.

Kemampuan pemecahan masalah sangat penting diberikan kepada siswa karena kemampuan siswa dapat terlatih dengan seringnya diberikan soal yang tidak rutin. Hal ini sejalan dengan pendapat Zulfah (2018) bahwa pemecahan masalah harus didasarkan atas adanya struktur kognitif yang dimiliki siswa. Bila tidak didasarkan atas struktur kognitif, siswa mempunyai kemungkinan kecil untuk dapat menyelesaikan masalah yang disajikan. Begitu pula dengan pendapat Rosmawati (2012:81) bahwa kemampuan pemecahan matematis merupakan bagian dari kurikulum matematika yang sangat penting, karna dapat membantu siswa mengembangkan keterampilan intelektual dan mengerjakan bagaimana memecahkan masalah menggunakan langkah-langkah pemecahan masalah.

Budiman menjelaskan 4 langkah penyelesaiaan kemampuan pemecahan masalah, yakni: mengidentifikasi kecukupan data untuk memecahkan masalah, membuat model matematika dari suatu masalah, memilih dan menerapkan strategi untuk menyelesaikan masalah matematika, serta memeriksa kebenaran hasil atau jawaban. Dalam penelitian ini, peneliti mengambil 4 langkah tersebut. (1) Mengidentifikasi kecupukan data, pada tahap ini siswa diminta untuk mencari infromasi apa yang diketahui, ditanyakan pada persoalan matematika dan apakah data tersebut sudah cukup, kurang atau berlebihan. Ketika siswa dapat menuliskan bahwa informasi yang didapat cukup, kurang atau bahkan berlebihan maka dapat memungkinkan siswa sudah memahami informasi yang tersaji dalam soal, (2) Membuat model matematika dari suatu masalah, pada tahap ini siswa memisalkan data yang sudah didapat pada tahap sebelumnya dengan variabel, (3) Memilih dan menerapkan strategi untuk menyelesaikan masalah matematika, di tahap ini siswa memilih strategi yang akan digunakan untuk bisa diterapkan untuk menyelesaikan persoalan matematika, dan (4) Memeriksa kebenaran hasil atau jawaban, di tahap terakhir ini siswa memeriksa kembali hasil jawaban yang telah dikerjakan apakah hasil dan prosedur yang digunakan benar. Materi dalam penelitian ini adalah aritmatika sosial.

\section{METODE PENELITIAN}

Penelitian ini adalah penelitian kualitatif deskriptif. Arikunto (2010) penelitian deskriptif merupakan penelitian yang bertujuan untuk mengetahui keadaan dan kondisi yang mana hasilnya 
dijelaskan dalam bentuk laporan penelitian, sehingga dapat mengetahui letak kesalahan-kesalahan siswa dalam menyelesaikan soal aritmatika sosial, sedangkan wawancara digunakan untuk memperkuat data hasil uraian tes kemampuan pemecahan masalah. Subjek penelitian ini adalah siswa kelas VIII-F di salah satu SMP Negeri di Batujajar yang berjumlah 36 orang. Instrumen pada penelitian ini adalah tes uraian berupa tes kemampuan pemecahan masalah dan wawancara. Penelitian ini menggunakan pendekatan kualitatif dengan metode deskriptif. Untuk membandingkan hasil tes dengan wawancara, peneliti menggunakan teknik triangulasi yang terdiri dari menentukan kesalahan jawaban siswa yang disesuaikan dengan hasil wawancara, dan menilai jawaban siswa berdasarkan tes yang diberikan. Untuk mengetahui banyaknya jenis kesalahan pada jawaban siswa (Ali, 1999) peneliti menggunakan rumus persentase berikut:

$$
\begin{aligned}
& P=\frac{n}{N} \times 100 \\
& \text { Keterangan : } \\
& \mathrm{P}=\text { Persentase Jenis Kesalahan } \\
& \mathrm{n}=\text { Banyaknya Kesalahan Untuk Masing-Masing Jenis Kesalahan } \\
& \mathrm{N}=\text { Banyaknya Kemungkinan Kesalahan Kriteria }
\end{aligned}
$$

Tabel 1.

Kriteria persentase banyaknya kesalahan

\begin{tabular}{cc}
\hline Persentase (P) & Kriteria \\
\hline $\mathrm{P} \geq 55 \%$ & Sangat Tinggi \\
$40 \% \leq \mathrm{P}<55 \%$ & Tinggi \\
$25 \% \leq \mathrm{P}<40 \%$ & Cukup Tinggi \\
$10 \% \leq \mathrm{P}<25 \%$ & Rendah \\
$\mathrm{P}<10 \%$ & Sangat Rendah \\
\hline
\end{tabular}

Berdasarkan tabel di atas, persentase kesalahan jawaban siswa sebesar 55\% mempunyai kriteria sangat tinggi, persentase kesalahan jawaban siswa antara 40\% sampai kurang 55\% mempunyai tinggi, persentase kesalahan jawaban siswa antara 25\% sampai kurang $40 \%$ mempunyai kriteria cukup tinggi, persentase kesalahan jawaban siswa antara 10\% sampai kurang 25\% mempunyai kriteria rendah, dan persentase jawaban siswa kurang dari $10 \%$ mempunyai kriteria $10 \%$ mempunyai kriteria sangat rendah.

\section{PEMBAHASAN}

Berdasarkan data hasil jawaban tes dan dari wawancara didapat tabel presentase kelima indikator kemampuan pemecahan masalah.

\section{Tabel 2.}

Presentase (P) Banyaknya Kesalahan Jawaban

\begin{tabular}{llll}
\hline Indikator & P Benar & P Salah & Kriteria Kesalahan \\
\hline Mengidentifikasi Kecukupan Data & 40,00 & 60,00 & Sangat Tinggi \\
Membuat Model Matematika & 57,14 & 42,86 & Tinggi \\
Memilih Strategi Penyelesaiaan & 59,29 & 40,71 & Tinggi \\
Menyelesaikan Masalah & 54,28 & 45,72 & Tinggi \\
\hline
\end{tabular}




\begin{tabular}{llll}
\hline Memeriksa Kembali Hasil Jawaban & 54,28 & 45,72 & Tinggi
\end{tabular}

Tabel 2 menunjukan 60\% siswa mengalami kesalahan dalam mengidentifikasi kecukupan data dalam memahami masalah pada soal aritmatika sosial dengan kriteria sangat tinggi, sebesar $42,86 \%$ siswa mengalami penurunan kesalahan ketika membuat atau mengubah data yang diperoleh kedalam model matematika dengan kriteria tinggi, kemudian pada tahap pemilihan strategi mengalami penurunan kesalahan sebesar $40,71 \%$ dengan kriteria tinggi, siswa mengalami penaikan kesalahan pada tahap penyelesaiaan masalah sebesar $45,72 \%$ dengan kriteria tinggi, presentase kesalahan tersebut sama besar pada tahap memeriksa kembali hasil jawaban dengan kriteria tinggi.

Di bawah ini, memaparkan skor tes kemampuan pemecahan masalah yang diperoleh dari 36 siswa.

Tabel 3.

Skor Kemampuan Pemecahan Masalah

\begin{tabular}{lll}
\hline Skor & Banyak Siswa & Keterangan \\
\hline 1 & 7 & Sangat Tidak Baik \\
5 & 9 & Tidak Baik \\
10 & 8 & Cukup Baik \\
15 & 6 & Baik \\
20 & 6 & Sangat Baik \\
\hline Jumlah & 36 & \\
\hline
\end{tabular}

Sebanyak 7 siswa dari 36 siswa sangat tidak baik dalam menyelesaikan soal tes kemampuan pemecahan masalah, mereka tidak dapat menjawab soal yang diberikan, walaupun mereka sudah mencoba namun hasil yang diperoleh salah sehingga memperoleh skor 1 . Terdapat 9 siswa tidak baik dalam menyelesaikan soal tes kemampuan pemecahan masalah, mereka hanya bisa memahami masalah, tetapi tidak dapat membuat model matematika, memilih strategi penyelesaian, menyelesaikan persoalan juga memeriksa kembali hasil jawaban sehingga mereka hanya memperoleh skor 5. Sebanyak 8 siswa cukup baik dalam menyelesaikan masalah, mereka dapat memahami masalah, membuat model matematika, walaupun pemilihan strategi dan juga hasil masih keliru sehingga mereka mendapatkan skor 10. Terdapat 6 siswa baik dalam menyelesaikan soal kemampuan pemecahan masalah, mereka sudah dapat memahami masalah, merencanakan strategi, juga menyelesaikan masalah tetapi terdapat salah satu indikator yang terlewatkan jadi skor yang diperoleh mereka adalah 15. Sebanyak 6 siswa sangat baik dalam menyelesaikan masalah, mereka sudah memenuhi kelima indikator kemampuan pemecahan masalah sehingga mereka mendapatkan skor 20 .

Tingkat kesalahan jawaban siswa terbanyak berada pada indikator mengidentifikasi kecukupan data atau memahami masalah. Sebesar 40,00\% siswa dapat memahami masalah dan 60,00\% siswa tidak dapat memahami masalah. Dapat dikatakan sebagian besar siswa masih belum memahami soal cerita aritmatika sosial. Pada indikator membuat model matematika sebesar 57,14\% siswa yang bisa membuat model matematika dan $42,86 \%$ siswa tidak bisa membuat model matematika. Kondisi ini dialami $17,14 \%$ dari $57,14 \%$. Sebesar $59,29 \%$ siswa dapat merencanakan strategi dalam 
penyelesaiaanya dan sebesar $40,71 \%$ siswa tidak bisa merencanakan strategi dalam penyelesaiaanya, dapat dinyatakan bahwa siswa yang bisa memahami soal, bisa membuat model matematika, belum tentu bisa menerapkan strategi pada penyelesaiaanya. Terlihat hanya sebesar $18,58 \%$ siswa bisa merencanakan strategi dalam menyelesaikan soal. Pada indikator penyelesaiaan masalah dan memeriksa kembali hasil jawaban mempunyai presentase yang sama yaitu sebesar 54,28\% siswa dapat menyelesaikan soal aritmatika dengan sangat baik dan sebesar $45,72 \%$ siswa tidak dapat menyelesaikan soal aritmatika dengan baik hal ini terjadi karna siswa tidak memahami masalah pada soal.

Hasil penelitian menunjukan berbagai kesalahan-kesalahan jawaban yang dialami siswa dalam menyelesaikan soal aritmatika sosial, berikut merupakan soal kemampuan pemecahan masalah yang diujikan ke siswa. Acila merupakan seorang siswa yang akan membeli peralatan sekolah ke toko langgananya. Ia membeli 6 penghapus dengan harga Rp. 6.000,00, 11 buku tulis dengan harga Rp. 33.000,00, setengah lusin buku garis tiga dengan harga satuan Rp. 4.025,00, dan sepertiga lusin penggaris dengan harga satuan Rp. 2.050,00. Berapakah uang yang harus dibayarkan Acila ke toko langgananya ?

Berdasarkan soal di atas, diperoleh berbagai jawaban dari siswa untuk setiap skor kemampuan pemecahan masaah. Berikut merupakan paparan salah satu jawaban siswa yang mendapatkan skor 1 .

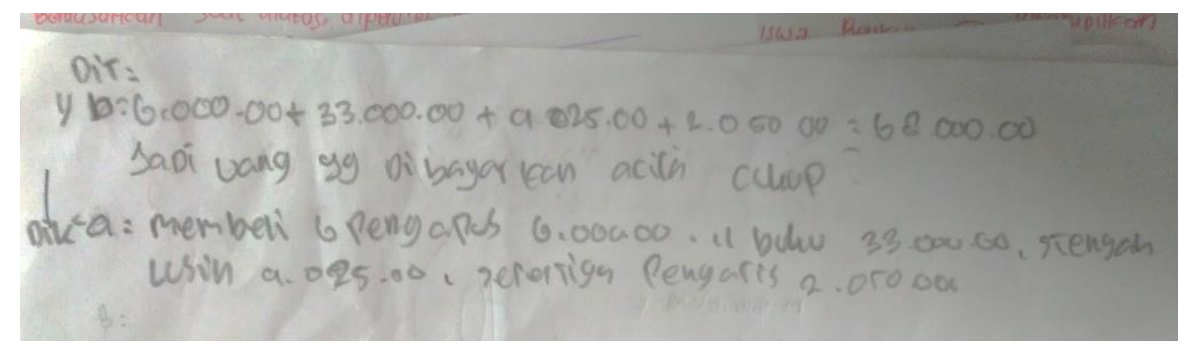

Gambar 1. Jawaban Siswa Yang Mendapatkan Skor 1

Berdasarkan jawaban siswa di atas, terlihat siswa mencoba menyelesaikan soal tersebut, akan tetapi terdapat kesalahan dalam hasil dikarenakan siswa kurang atau tidak memahami soal yang diberikan. Hal tersebut sesuai dengan penelitian yang telah dilakukan oleh Putra, Putri, Lathifah, dan Mustika (2018), bahwa siswa mencoba menyelesaikan soal, meskipun mereka tidak memahami soal yang diberikan yang mengakibatkan terjadinya kesalahan pada jawaban siswa. Selanjutnya, tahap membuat model matematika tidak tampak pada jawaban di atas. Siswa langsung ke tahap menyelesaikan masalah, pemilihan strategi atau cara juga tidak tampak siswa tuliskan untuk menyelesaikan soal tersebut. Karna terjadi kesalahan di awal tahap memahami masalah, mengakibatkan siswa mengalami kesalahan pada tahap selanjutnya. Sehingga untuk tahap memeriksa kebenaran hasil jawabanpun memiliki kesalahan. Secara keseluruhan siswa yang tidak dapat menyelesaikan masalah ini terdapat 8 siswa. Dapat dikatakan kemampuan pemecahan masalah siswa 
dikategorikan sangat tidak baik. Situasi ini menunjukan siswa belum terbiasa mengerjakan soal tidak ruyin (berbeda-beda). Sejalan dengan penelitian Muslim (2017) bahwa terdapat beberapa siswa disalah satu sekolah menengah yang merasa kesulitan dalam mengerjakan soal tidak rutin dari biasanya. Hasil wawancara menunjukan faktor penyebab siswa mengalami kesalahan dalam menyelesaikan soal yang diberikan dikarenakan pemahaman siswa tidak baik. Siswa tidak memahami informasi pada soal yang diberikan. Meskipun siswa sudah mencoba menuliskan informasi yang didapat menurut pemahaman sendiri, tetapi hasil jawaban tersebut keliru, akibatnya penyelesaiaan yang didapat tidak benar. Berikut cuplikan jawaban siswa yang mendapat skor 5

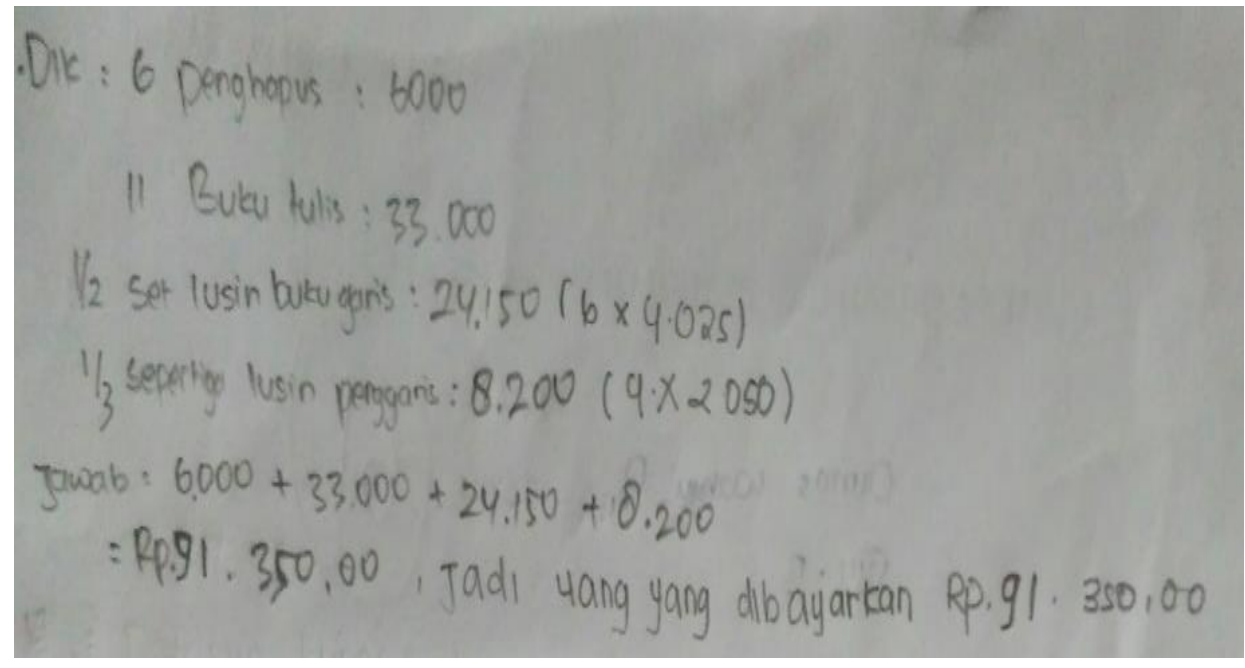

Gambar 2. Jawaban siswa yang mendapatkan skor 5

Gambar 2 menunjukan siswa sudah bisa memahami informasi pada soal, hal ini terlihat dengan siswa menuliskan apa yang diketahui pada soal yaitu: harga 6 penghapus adalah Rp. 6.000,00, harga 11 buku tulis adalah Rp. 33.000,00, harga $\frac{1}{2}$ lusin buku garis tiga adalah Rp. 24.150,00, harga $\frac{1}{3}$ lusin penggaris adalah Rp. 8.200,00. Akan tetapi tidak tampak siswa memisalkan data yang sudah diperoleh di tahap sebelumnya kedalam model matematika. Kemudian siswa sudah menerapkan strategi pada penyelesaiaan di atas, akan tetapi hasil yang diperoleh kurang tepat. Walaupun siswa sudah menuliskan strategi kemudian hasilnya, tetapi jawabannya masih keliru. Dapat dipastikan pada tahap terakhir, siswa tidak memeriksa hasil yang sudah dikerjakan di akhir penyelesaiaan hal ini terlihat, siswa melakukan kesalahan pada tahap kedua yang mengakibatkan timbulnya kesalahan pada tahap selanjutnya. Berdasarkan hasil wawancara, siswa sudah dapat memahami informasi yang terdapat pada soal. Namun siswa mengalami kendala, dalam melakukan perhitungan dikarenakan susah ucapnya juga siswa tersebut lupa dalam mengubah data ke dalam model matematika. Hal tersebut terjadi karena siswa lalai dalam pengerjaan soal sehingga terdapat 1 indikator yang terlewatkan juga siswa kurang lancar dalam mengoperasikan perhitungan penjumlahan sehingga hanya memperoleh skor 5. Untuk cuplikan jawaban siswa yang mendapat skor 10 adalah sebagai berikut. 


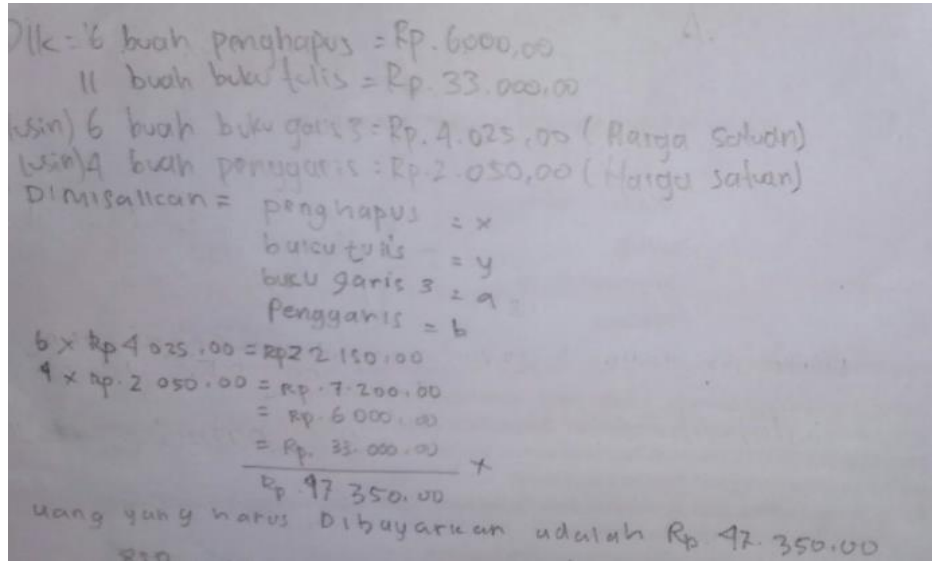

Gambar 3. Jawaban siswa yang mendapatkan skor 10

Berdasarkan gambar 3, siswa sudah memahami informasi pada soal, hal ini terlihat siswa menuliskan apa yang diketahui menurut pemahaman siswa sendiri, harga 6 penghapus adalah Rp. 6.000,00, harga 11 buku tulis adalah Rp. 33.000,00, $\frac{1}{2}$ lusin 6 buah buku garis tiga adalah Rp. 4.025,00 (harga satuan), harga $\frac{1}{3}$ lusin 4 buah penggaris adalah Rp. 2.050,00 (harga satuan). Terlihat siswa sudah dapat memisalkan data perlatan tulis yang diperoleh pada tahap sebelumnya ke dalam model matematika. Seperti, penghapus (x), buku tulis (y), buku garis 3 (a), dan penggaris (b). Kemudian siswa langsung ke tahap penyelesaian tanpa menerapkan cara dari penyelesaian tersebut, yang mengakibatkan siswa mengalami kesalahan pada hasil yang diperoleh. Sehingga, dapat dikatakan siswa tidak memeriksa kembali hasil jawaban, dapat terlihat dengan siswa melakukan kesalahan dengan tidak menerapkan cara untuk penyelesaiaanya yang mengakibatkan timbulnya kesalahan pada tahap selanjutnya. Berdasarkan hasil wawancara, siswa sudah memahami soal dengan menuliskan informasi apa yang diketahui pada soal, kemudian siswa juga sudah bisa membuat pemisalan dari data yang diperoleh kedalam model matematika. Akan tetapi siswa masih mengalami kendala dalam melakukan operasi, terlihat pada jawaban di atas siswa mencoba mengoperasikan hasil perhitunganya namun masih keliru. Ini disebabkan karna siswa kurang lancar dalam mengoperasikan perhitungan perkalian dan penjumlahan sehingga skor yang diperoleh hanya 10. Gambar 4 berikut memaparkan jawaban siswa yang mendapat skor 15

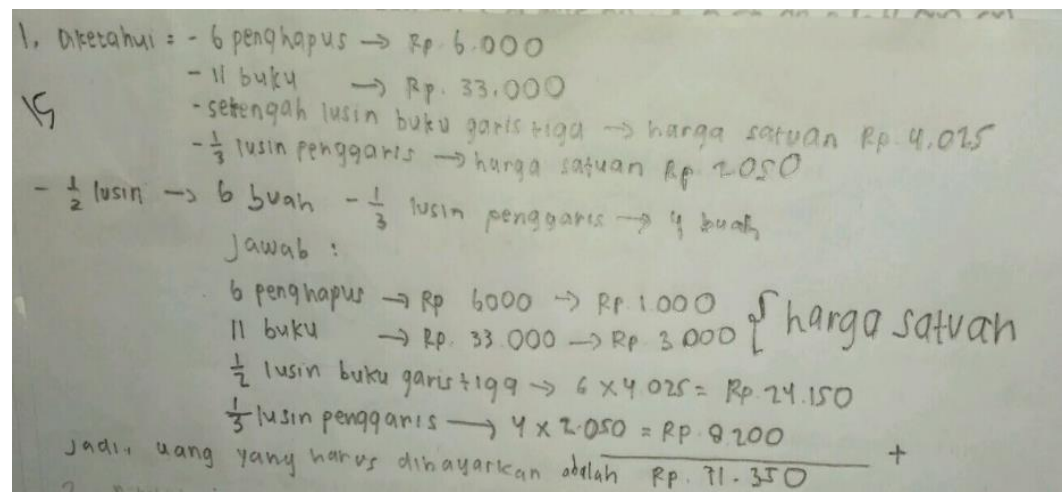

Gambar 4. Jawaban siswa yang mendapat skor 15 
Gambar di atas menunjukam siswa sudah dapat mengetahui jumlah uang yang harus dibayarkan untuk pembelian 6 penghapus, 11 buku tulis, $\frac{1}{2}$ lusin buku garis tiga dan $\frac{1}{3}$ lusin penggaris seharga Rp. 71.350,00. Pada tahap pertama siswa sudah memahami informasi pada soal, pada tahap merencanakan penyelesaiaan siswa dapat menerapkan cara untuk menyelesaikan soal tersebut. Sehingga hasil yang diperoleh tepat dan benar, siswa dengan penyelesaiaan seperti di atas memperoleh skor 15 disebabkan siswa tidak menuliskan data yang sudah diketahui kedalam bentuk model matematika. Sehingga untuk tahap memeriksa hasil jawaban tidak siswa lakukan, dapat terlihat adanya indikator kemampuan pemecahan masalah yang terlewatkan yaitu mengubah data yang sudah diperoleh sebelumnya ke dalam model matematika. Berdasarkan hasil wawancara siswa lupa mengubah data ke dalam model matematika ucapnya, dapat dikatakan siswa tersebut tergesa-gesa dalam mengerjakan soal.

Gambar 5, menampilkan jawaban siswa yang memperoleh skor 20

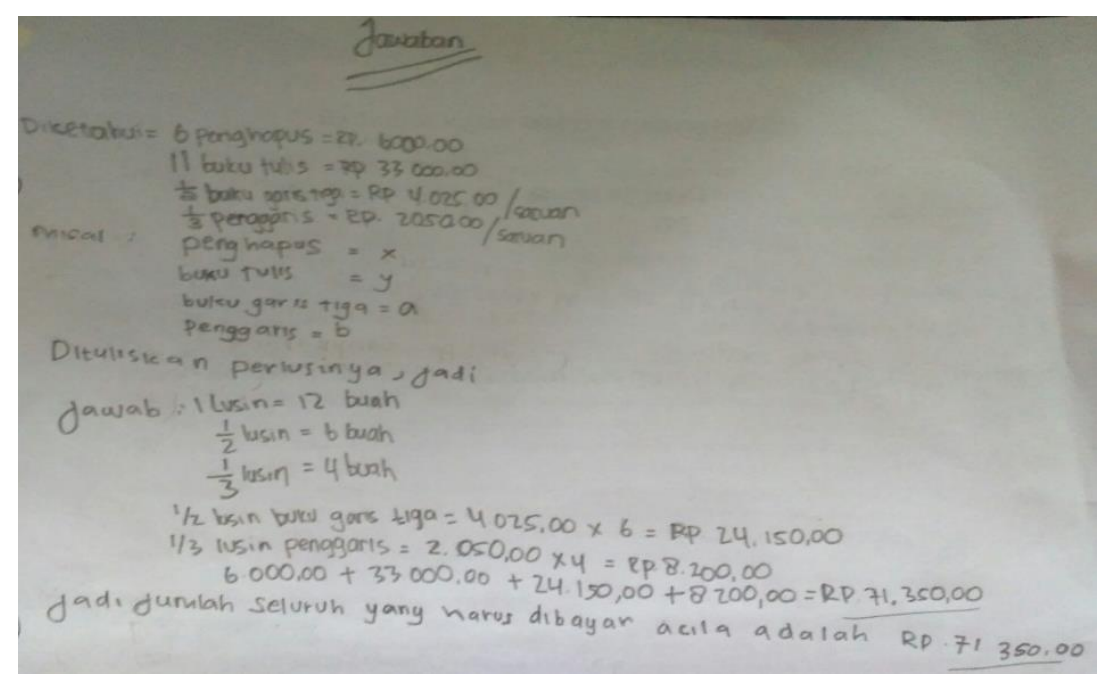

Gambar 5. Jawaban siswa yang mendapat skor 20

Berdasarkan gambar di atas, menunjukan siswa memahami masalah. Biasanya siswa menuliskan kembali informasi yang diketahui dan ditanyakan pada soal dalam memahami masalah, Susanti (2017). Pada jawaban di atas siswa menuliskan informasi pada soal, harga 6 penghapus adalah Rp. 6.000,00, harga 11 buku tulis adalah Rp. 33.000,00, harga $\frac{1}{2}$ lusin buku garis 3 adalah Rp. 4.025,00 (harga satuan), harga $\frac{1}{3}$ lusin penggaris adalah Rp. 2.050,00 (harga satuan). Terlihat siswa juga memisalkan peralatan tulis tadi kedalam bentuk matematika, seperti penghapus (x), buku tulis (y), buku garis tiga (a), dan penggaris (b). Pada tahap merencanakan penyelesaiaan siswa sudah bisa menentukan $\frac{1}{2}$ lusin buku garis tiga adalah 6 buah, kemudian terlihat siswa mengalikan harga satuan buku garis tiga dengan banyaknya $\frac{1}{2}$ lusin buku yaitu 6 buah. Begitupun dengan $\frac{1}{3}$ lusin penggaris siswa juga dapat menentukan bahwa terdapat 4 buah. Kemudian siswa menjumlahkan hasil yang telah diperoleh di tahap sebelumnya. Kemampuan berhitung siswa sangat baik sehingga diperoleh hasil yang tepat dan benar. Pada tahap penyelesaiaan, siswa sudah dapat menentukan jumlah yang harus 
dibayarkan untuk pembelian 6 penghapus, 11 buku tulis, $\frac{1}{2}$ lusin buku garis tiga, dan $\frac{1}{3}$ lusin penggaris seharga Rp. 71.350,00. Dapat dipastikan siswa dengan jawaban di atas memperoleh skor 20, dengan memenuhi 5 indikator. Sehingga kemampuan pemecahan masalah siswa ini sangat baik. Pada tahap terakhir dapat dipastikan juga siswa memeriksa kembali jawaban yang telah dikerjakan, terlihat dari hasil yang didapat benar dan memenuhi 5 indikator kemampuan pemecahan masalah. Berdasarkan hasil wawancara siswa tidak mengalami kesulitan dalam menyelesaikan soal. Siswa dapat memahami soal dengan baik, kemampuan siswa dalam mengoperasikan perhitungan juga sangat baik sehingga hasil yang diperoleh benar dan tepat. Dari 36 siswa hanya terdapat 7 siswa yang memperoleh skor 20, dengan menyelesaikan soal sesuai dengan kelima indikator kemampuan pemecahan masalah.

\section{KESIMPULAN}

Berdasarkan analisis kemampuan pemecahan masalah, dapat disimpulkan bahwa kesalahan yang dilakukan siswa terbanyak pada indikator memahami masalah. Sejalan dengan penelitian Irma, A., Herlina, D., \& Nelson, Z. (2018) kemampuan pemecahan masalah merupakan salah satu kemampuan yang harus dikuasai oleh siswa dan menjadi salah satu tujuan pembelajaran matematika. Namun kenyataannya masih banyak siswa yang mengalami kesulitan dalam memahami permasalahan yang ada dalam soal matematika. Siswa tidak bisa memahami soal pada materi aritmatika sosial. pada indikator membuat model matematika, memilih strategi penyelesaiaan, menyelesaikan masalah, dan memeriksa kembali hasil jawaban hanya sebagian siswa yang dapat mengerjakan pada tahap ini. Dapat dikatakan bahwa kemampuan pemecahan masalah di SMPN 3 Cimahi masih rendah, sehingga siswa perlu dibiasakan diberikan soal tidak rutin atau soal kemampuan pemecahan masalah untuk melatih kemampuan siswa.

\section{DAFTAR PUSTAKA}

Abdurrahman, Mulyono. (2010:252). Pendidikan Bagi Anak Kesulitan Belajar. Jakarta: Pt Andi Mahastya

Arikunto, S. (2010). Prosedur Penelitian (Suatu Pendekatan Praktik). Bandung: Rineka Cipta.

Ali, M. (1999). Strategi Penelitian Pendidikan. Bandung: Rineka Cipta.

Hendra, H. (2018). Peningkatan Hasil Belajar Matematika Siswa Kelas XI IPA Sman Negeri 1 Bangkinang melalui Model Pembelajaran Kooperatif Tipe Stad. Jurnal Cendekia: Jurnal Pendidikan Matematika, 2(2), 29-41.

Irma, A., Herlina, D., \& Nelson, Z. (2018). Pengaruh Penerapan Model Pembelajaran Kooperatif Tipe Student Teams-achievement Divisions (Stad) terhadap Kemampuan Pemecahan Masalah Matematis Ditinjau dari Kemampuan Awal Siswa Sekolah Menengah Pertama Tualang. Jurnal Cendekia: Jurnal Pendidikan Matematika, 2(2), 54-60. 
Limardani, Gathut., D. Trapsilasiwi \& A. Fatahillah. (2015). Analisis Kesulitan Siswa Dalam Menyelesaikan Soal Operasi Aljabar Berdasarkan Teori Pemahaman Skemp Pada Siswa Kelas VIII D SMP Negeri Jember. Jember: Universitas Negeri Jember

Muslim, S. R. (2017). Pengaruh Penggunaan Model Project Based Learning terhadap Kemampuan Pemecahan Masalah Matematika Peserta Didik SMA. SJME (Supremum Journal of Mathematics Education), 1 (2), 88-95.

Putra, H. D., Putri, A., Lathifah, A. N., \& Mustika, C. Z. (2018). Kemampuan Mengidentifikasi Kecukupan Data pada Masalah Matematika dan Self-Efficacy Siswa MTs. Jurnal Nasional Pendidikan Matematika, 2(1), 48-61.

Putra, H. D., Putri, W. A. S., Fitriana, U., \& Andayani, F. (2018). Kemampuan Pemecahan Masalah Matematis dan Self-Confidence Siswa SMP. SJME (Supremum Journal of Mathematics Education), 2(2), 60-70.

Susanti, V. D. (2017). Profil Pemahaman Mahasiswa dalam Memecahkan Masalah pada Mata Kuliah Matematika SMP Ditinjau dari Multiple Inteligence. SJME Supremum Journal of Mathematics Education), 1 (2), 57-67.

Rosmawati, Elniati, S, Murni, D. (2012). Kemampuan Pemecahan Masalah Dan Lembar Kegiatan Siswa Berbasis Problem Solving. Jurnal Pendidikan Matematika, Vol. 1 No. 1

Runtukahu Dan Kandou. (2014:252). Matematika Dasar Bagi Anak Berkesulitan Belajar. Yogyakarta: Ar-Ruzz Media.

Untari, Erny. (2014). Diagnosis Kesulitan Belajar Pokok Bahasan Pecahan pada Siswa Kelas V Sekolah Dasar. Jurnal Ilmiah Stkip Pgri Ngawi, 13(1):1-8

Zulfah, Z. (2017). Pengaruh Penerapan Model Pembelajaran Kooperatif Tipe Think Pair Share Dengan Pendekatan Heuristik Terhadap Kemampuan Pemecahan Masalah Matematis Siswa Mts Negeri Naumbai Kecamatan Kampar. Jurnal Cendekia: Jurnal Pendidikan Matematika, 1(2), 1-12. 